\title{
THE EFFECT OF TERROR EVENTS ON FINANCIALL MARKETS
}

Dr. Yoser Gadhoum ${ }^{\mathrm{a}}$, Abeer Aldawsari ${ }^{\mathrm{b}}$, Halah Almusbeh ${ }^{\mathrm{c}}$ abc Prince Mohammad Bin Fahd University, Alkhobar, Saudi Arabia Corresponding email: halah.almusbeh@gmail.com

\begin{abstract}
- Turkey Airport Bombing.
- Yemen Civil War.

- Al Masjed Al Nabawy Holy Mosque Bombing.

- Manhattan Street Bombing.

- Egyptian Airplane Kidnaping.
\end{abstract}

Abstract

This world is exposed to evil and damage. Terror attacks, for instance, are a way for terrorists to relatively express their anger or revenge, whether for political or religious motives. However, in this report, we are analyzing the stock market's reaction in order to show the impact of terror attacks on market integration and determine the level of sensitivity of the international stock market towards these attacks on the day of the attacks. We have chosen five different terror attacks $\backslash$ events in the year 2016 from different areas around the world and they are as follows:

The subject markets for analysis in this report are New York Stocks Exchange Market, Tokyo Stock Exchange, Germany Stock Market, Saudi Stock Market, United Arab Emirates Stock Exchange and Qatar Stock Exchange. After deep analysis, we found the followings:

- USA stock market shows positive autocorrelation in the times Saudi Arabia was hit by the Yemen Civil War and Al Masjed Al Nabawy Holy Mosque Bombing.

- All markets show positive autocorrelation due to the event of Al Masjed Al Nabawy Bombing.

- Saudi Arabia Stock Market shows positive autocorrelation on only Saudi terror events or \and USA terror events.

- Saudi Arabia and USA stock markets are the most integrated markets.

- Tokyo and Germany stock markets show positive autocorrelation due to events in the Middle East.

- UAE and Qatar stock markets are the least sensitive toward terror attacks.

- USA, Saudi Arabia and Tokyo are the most sensitive markets towards terror attacks.

- International stock markets can be affected by terror attacks immediately and for the shortterm only.

Keywords: Terror Attacks, Stock Exchange, Market Integration. 


\section{Introduction}

\subsection{What is Behavioral Finance?}

Behavioral Finance is the criterion where financial market exchanges are being studied using different models that are considered less narrow than those based on Von NeumannMorgenstern expected utility theory and arbitrage hypotheses. Particularly, behavioral finance has two construction blocks: Cognitive Psychology and the Limits to Comparison Arbitrage. The cognitive side applies to how people think. People are not $100 \%$ balanced all the time. It can appear in investors' attitudes towards risk. When making a risky decision, people are very loath to incur losses. It seems that investors do not focus only on the current value of their money; however, they tend to check back their investments if they are showing loss or profit. This attitude introduces us to the "Prospect Theory" which states that the value investors put on a particular outcome is determined by the losses or the gains that they have got since the asset was possessed. Also, investors are reluctant to the possibility of even a very small loss and need a high return to recompense for it. Once investors lose money; their only concern will be not to risk additional loss. On the contrary, the "Portfolio Theory" is when the investors are focusing on the future. Past losses or returns are not considered. The primary interest is the investor's current stock and the expectation and risk of more wealth.

Psychology research shows that people make systematic errors in the way they think. They are overconfident about their financial decisions, or they overweight the recent experiences. Their preferences also could be misleading. People make systematic errors in assessing the likelihood of uncertain events. Psychologists have found that, when deciding possible future outcomes, people tend to flashback at what they have experienced before in some similar circumstances. Therefore, they are influenced to place too much on a small number of previous cases. Also, most people are considered rather conservative, that is, too difficult or slow to renew their views in in the face of new findings. Another systematic preference is over-confidence; most investors think they are smart stock pickers. Over-confidence also shows up in the certainty that people expose their decisions. They overestimate the odds and underestimate the risks of unlikely events.

\subsection{Limits of Arbitrage:}

Behavioral finance uses limits to arbitrage that refer to predicting in what circumstances arbitrage powers will have an effect, and when they will not be. One reason that there are limits to arbitrage, that's restrictions on the ability of the rational investors to utilize market inefficiencies to their benefits. On the other hand, arbitrage means an investment plan that ensures high returns without going through any risk. Traditionally, arbitrage is a strategy that exploits market inefficiency and generates greater outcomes if prices return to original values. This strategy can be very rewarding, but it is high in risk. An example of an assumption about people's preferences, a $\$ 20$ gain might make people feel good by as much as a $\$ 10$ loss makes them feel bad. Inaccurate beliefs occur because people are wrong predictors. Modern finance has as another construction block which is the "Efficient Markets Hypothesis" (EMH). The EMH argues that any competition among investors who seek significant abnormal profits drives prices to their "actual" value. The "Efficient Markets Hypothesis" does not assume that all investors are logical or rational, but it does assume that markets are rational for sure. EMH does 
not assume that markets can anticipate the future, but it does assume that markets make clear, unbiased forecasts of the future. In contrast, behavioral finance believes that, in some circumstances, financial markets are informationally inefficient.

\section{Research Motivation}

\subsection{The Effects of Terror Attacks}

This report is not going to be only about Behavioral Finance; however, the least will play a major role in showing the decision making of investors under special circumstances. One of these is terrorism around the world. Despite the many different reasons and motives behind committing terrorist attacks, whether political or religious, no one can deny the terrible effects of terror on any community.

Moreover, we investigate the effects of terror on economy and financial markets. Evidence will be shown from five different international financial markets: New York Stocks Exchange Market, Tokyo Stock Exchange, Germany Stock Market, Saudi Stock Market, United Arab Emirates Stock Exchange and Qatar Stock Exchange. During past years, due to the increasing number of terror events around the world, a growing interest from academics has been devoted to investigating the effects of terror shocks on the macro-economy. Terror has damaging and significant and short-term effects on primary macroeconomic variables such as investment, consumption, and net exports. Basically, many researches argue that prices of individual stocks reflect investors' fears and hopes about the future. Investors can be affected to exist the market searching for other and more stable financial instruments when any information about any terrorist events are emerged as well as any other unforeseen disastrous, although the high liquidity of the stock market. Karolyi \& Martell, (2005) analysed the stock price impact of terrorist attacks by using an event study approach for different events in different countries, and have shown that the losses caused by terror attacks are significant when the targets are located in more democratic and richer countries. Also, Chen \& Siems (2004) used an event study methodology to examine how terror affects global capital markets. They conclude that the U.S. capital financial markets recover more quickly from terrorist attacks than other global capital financial markets. Moreover, by using a time-series approach,

Eldor \& Melnick (2004) "showed that Financial markets are efficient in pricing the shocks associated with terrorist attacks". However, Johnston and Nedelescu, (2005) reviewed this issue from a different aspect, looking at the main events occurring around the world, they debate how effective the reaction of the relevant authorities and coordinated efforts can help financial markets to be efficient in absorbing the shocks caused by terrorist events.

\subsection{Terror Events}

We have selected five different terror attacks as subject of study to show the reaction of the indices' of the market in USA, Europe, KSA and other GCC countries as mentioned above. The events are ordered chronologically from the most recent:

First, is the "Manhattan Street Bombing" located in Manhattan, New-York City on the $17^{\text {th }}$ September, 2016. The NYPD reported that three bombs were exploded on a street in Manhattan, 29 people were injured and no one was killed. More bombs were found at other locations in Manhattan and nearby New Jersey but were securely detonated by the police (New York Times, 2016). 
Second, is the "Al-Masjed Al-Nabawai Bombing", a suicide attack was committed outside Al-Masjid Al-Nabawy Holy Mosque by five people who were killed in the incident on the $4^{\text {th }}$ July, 2016. Saudi Ministry of Interior reported the death of four police officers. This bombing was the third terror attack that targeted the kingdom on that day, following other blasts in the Qatif and Jeddah (Aljazeera, 2016).

Third, is the "Turkey International Airport Attack", Turkish officials reported that Turkish police fired on the suspects who then blew themselves up after the security checkpoint at an international terminal in the airport, 41 people were killed and more than 230 were injured. The incident took a place on the $28^{\text {th }}$ June, 2016 (BBC, 2016).

Fourth, is the "Egyptian Airplane Kidnapping", flight had been hijacked by a man whom the officials described as "unstable". The kidnapper held the crew and passengers as hostages with a fake explosive belt, forcing the plane to be directed to Cyprus. The incident ended relatively peacefully and the hijacker was captured by the authorities and put into custody immediately after landing. The incident took a place on the $29^{\text {th }}$ March, 2016 (Eliott, 2016).

Finally, is the famous 'Yemen Civil War", a political conflict that started officially on the $22^{\text {nd }}$ March, 2015 up to present, between the Saudi Government and "Al-Houthi" Yamani tribe (BBC, 2016).

\section{Research Methodology}

In this paper, we look at the behaviour of stock markets volatility to shocks produced by terror events in five different countries and six stock markets. The purpose of this study is to look at the two different dimensions: "Sensitivity of the Market" and "Market Integration" of stock returns and test whether terror attacks have an impact of investors' sentiments within different time-series framework.

It is important to mention the integrated markets which can be defined as markets where prices for comparable assets do not behave independently. If markets are integrated well, it can be expected that market forces are working in a proper way. Implying that price changes in a particular location are consistently related to other price changes in other markets and locations whom its agents can interact with different markets.

Regardless of location, in countries that are fully integrated into the world financial market carry assets with an identical risk that should command the same anticipated return, since domestic investors can purchase foreign assets and on the other hand foreign investors can get domestic assets. Also, it is important to determine exactly when a market becomes fully integrated. Usually, the date of a particular regulatory change is utilized as a proxy for the timing of integration of equity markets. But, this can be misleading for the investors. In reality, regulatory changes may have little or no impact at all on the functioning of the capital market. There are many ways to deceive capital controls, and thus to get indirect access to financial markets, even if a market is technically closed to the foreign investors. The variables that can be related to the integration process are:

1. Financial information related to price levels.

2. Financial variables that are related to local market liquidity.

3. Capital flow variables to the market.

4. Co-movement of returns and local economic climate that includes exchange rate volatility, inflation rates and size of the trading sector. 
The other dimension is the Sensitivity Analysis which its techniques are necessary to determine how various values of an independent variable affect another dependent variable under a set of assumptions. This technique is used within appropriate boundaries that depend on one or more input variables, like the factor that changes in interest rates have on bond prices. When breaking down Sensitivity Analysis, is it a useful way to predict the result of a decision given a specified range of variables. By that, the analyst can determine how changes in one variable affect the outcome.

\section{Findings}

In the study of the market reaction towards the terror attacks, we based our analysis on the autocorrelation to further understand the strength of the relationship between the events and the market, and further more between one market and another.

\section{1 Preliminary Results}

Based on the calculation made, the stock market price on the event date, the autocorrelation percentage was calculated to measure the strength between the event and the market price, accordingly the value 1 would represent the percentage of autocorrelation when it is less than 0 , in which we say that we have a perfect negative correlation. In the other hand, the -1 would represent if the percentage of autocorrelation was more than $\mathrm{o}$, which means that have a perfect positive correlation, table (1-1).

Table (1 - 1): Autocorrelation of Events across Markets

\begin{tabular}{|c|c|c|c|c|c|c|}
\hline Event/Market & USA & $\begin{array}{l}\text { German } \\
\mathbf{y}\end{array}$ & KSA & UAE & Qatar & Tokyo \\
\hline $\begin{array}{r}\text { Turkey Airport } \\
\text { Bombing }\end{array}$ & 1 & 1 & 1 & 1 & 1 & 1 \\
\hline $\begin{array}{c}\text { Yemen Civil } \\
\text { War }\end{array}$ & -1 & 1 & 1 & 1 & 1 & -1 \\
\hline $\begin{array}{c}\text { Al-Masjed Al } \\
\text { Nabawi } \\
\text { Bombing } \\
\end{array}$ & -1 & -1 & -1 & -1 & -1 & -1 \\
\hline $\begin{array}{l}\text { Manhattan } \\
\text { Street } \\
\text { Bombing }\end{array}$ & 1 & 1 & -1 & 1 & 1 & 1 \\
\hline $\begin{array}{r}\text { Egypt Airplane } \\
\text { Kidnaping }\end{array}$ & 1 & -1 & 1 & 1 & 1 & -1 \\
\hline
\end{tabular}




\section{2 Analysis of Results}

As mentioned before, we based our analysis and study on autocorrelation, and because the stock market changes on a daily basis from opening/closing and adjustment prices, in addition to the difference of closing dates from one country to another; due to holidays or weekends, to come up with a closer idea to the affect, we had to take in consideration the average of autocorrelation rates; 2 days prior to the event, and 2 days post event, in addition to the event day, across markets, accordingly we built table (1-2) to represent the average rates of autocorrelation for our five terror attacks events across the six markets. Additionally, we measured the strength rate/relationship, but this time between markets, to detect the impact of them affected by one event across each other, and it is represented as percentages in table (1-3).

Table (1 - 2): Average of Autocorrelation

\begin{tabular}{|c|c|c|c|c|c|c|}
\hline Event/Market & USA & $\begin{array}{l}\text { German } \\
\mathbf{y}\end{array}$ & KSA & UAE & Qatar & Tokyo \\
\hline $\begin{array}{r}\text { Turkey Airport } \\
\text { Bombing }\end{array}$ & $-3 \%$ & $-6 \%$ & $-1 \%$ & $-1 \%$ & $-1 \%$ & $-3 \%$ \\
\hline Yemen Civil War & $1 \%$ & $-2 \%$ & $-2 \%$ & $-1 \%$ & $-2 \%$ & O\% \\
\hline $\begin{array}{r}\text { Al-Masjed Al } \\
\text { Nabawi } \\
\text { Boming } \\
\end{array}$ & $3 \%$ & $1 \%$ & o\% & $3 \%$ & $1 \%$ & $1 \%$ \\
\hline $\begin{array}{r}\text { Manhattin Street } \\
\text { Bombing }\end{array}$ & $-1 \%$ & $-1 \%$ & $1 \%$ & o\% & $-2 \%$ & $-2 \%$ \\
\hline $\begin{array}{r}\text { Egypt Airplane } \\
\text { Kiddnap }\end{array}$ & $0 \%$ & $1 \%$ & $-3 \%$ & $-2 \%$ & $-1 \%$ & $0 \%$ \\
\hline
\end{tabular}

Table (1 - 3): Average of Autocorrelation

\begin{tabular}{|c|c|c|c|c|c|c|}
\hline Markets & USA & Germany & KSA & UAE & Qatar & Tokyo \\
\hline USA & $100 \%$ & & & & & \\
\hline Germany & $73 \%$ & $100 \%$ & & & & \\
\hline KSA & $3 \%$ & $-19 \%$ & $100 \%$ & & & \\
\hline
\end{tabular}




\section{Asia Pacific Journal of Advanced Business and Social Studies \\ ISBN (eBook): 9780994365675 I ISSN : 2205-6033 \\ Year: 2017 , Volume: 3, Issue: 2

\begin{tabular}{|c|cccccc|} 
UAE & $77 \%$ & $44 \%$ & $59 \%$ & $100 \%$ & & \\
Qatar & $34 \%$ & $22 \%$ & $43 \%$ & $74 \%$ & $100 \%$ & \\
Tokyo & $90 \%$ & $84 \%$ & $-38 \%$ & $43 \%$ & $8 \%$ & $100 \%$ \\
\hline
\end{tabular}

On the other hand, we did the calculation of the F-statistic or, as it is also known, the Fratio, which is equal to MSR/MSE, to measure the strength in our regression analysis between the events and the markets. After we came out with the value of it, we crosscheck the F-Distribution against the alpha value of 6.61, to reach to the below outcome, the significant value/degree to the probability, table (1-4). Accordingly, we measured the degree of significant between the markets, across each other, and it is represented as percentages in table (1-5).

Table (1 - 4): The Significant Analysis (F-Ratio vs. 6.61)

\begin{tabular}{|c|c|c|c|c|c|c|c|c|}
\hline Event/Market & USA & $\begin{array}{c}\text { German } \\
\mathbf{y}\end{array}$ & KSA & UAE & Qatar & Tokyo & Significant & $\begin{array}{l}\text { Not } \\
\text { Significan } \\
t\end{array}$ \\
\hline $\begin{array}{l}\text { Turkey } \\
\text { Airport } \\
\text { Bombing }\end{array}$ & $\mathrm{O}$ & 0 & $\mathrm{O}$ & 0 & $\mathrm{O}$ & 0 & $\mathrm{O}$ & 6 \\
\hline $\begin{array}{c}\text { Yemen Civil } \\
\text { War }\end{array}$ & $\mathrm{O}$ & 0 & $\mathrm{O}$ & 0 & $\mathrm{O}$ & 0 & $\mathrm{O}$ & 6 \\
\hline $\begin{array}{c}\text { Al-Masjed Al } \\
\text { Nabawi } \\
\text { Bombin } \\
\text { g }\end{array}$ & O & 0 & 1 & 1 & 1 & 0 & 3 & 3 \\
\hline $\begin{array}{c}\text { Manhattan } \\
\text { Street } \\
\text { Bombing }\end{array}$ & $\mathrm{O}$ & 0 & $\mathrm{O}$ & 1 & 1 & 0 & 2 & 4 \\
\hline $\begin{array}{c}\text { Egypt } \\
\text { Airplane } \\
\text { Kidnap }\end{array}$ & 1 & 0 & 1 & 0 & o & 0 & 2 & 4 \\
\hline Significant & 1 & 0 & 2 & 2 & 2 & 0 & 7 & \\
\hline
\end{tabular}

Asia Pacific Institute of Advanced Research (APIAR) 


\section{Asia Pacific Journal of Advanced Business and Social Studies \\ ISBN (eBook): 9780994365675 | ISSN : 2205-6033 \\ Year: 2017, Volume: 3, Issue: 2}

\section{\begin{tabular}{c|lllllll}
$\begin{array}{c}\text { Not } \\
\text { Significant }\end{array}$ & 4 & 6 & 3 & 3 & 3 & 6
\end{tabular}}

Table (1 - 5): The Degree of Significant (Markets vs. Markets)

\begin{tabular}{|c|c|c|c|c|c|c|}
\hline Markets & USA & Germany & KSA & UAE & Qatar & Tokyo \\
\hline USA & $100 \%$ & & & & & \\
\hline Germany & о\% & о\% & & & & \\
\hline KSA & $61 \%$ & o\% & $100 \%$ & & & \\
\hline UAE & $-41 \%$ & o\% & $17 \%$ & $100 \%$ & & \\
\hline Qatar & $-41 \%$ & o\% & $17 \%$ & $100 \%$ & $100 \%$ & \\
\hline Tokyo & ०\% & о\% & о\% & o\% & о\% & o\% \\
\hline
\end{tabular}

\section{Conclusion}

In conclusion, no one can deny the massive effects of terror attacks either politically, socially or economically. The data analysis made in this report highlights on the fact that terror attacks have a damaging and a significant short-term effect on international stock market in general, primarily on macroeconomic variables. Stock markets in the countries where terror attacks take place react more sensitively than other stock markets in different countries.

As a result of the autocorrelation analysis, it showed that area of market integration between international stock markets is relatively large between USA and Saudi Arabia stock markets, while the market integration in both UAE and Qatar is considered small against other stock markets. However, we noticed from the analysis that all stock markets were greatly affected in Al Masjed Al Nabawy Bombing as an Islamic point. Also, the analysis showed that Germany is sensitively high towards terror attacks in the Middle East countries as well as Tokyo stock markets. Finally, based on the autocorrelation analysis, we found that USA Saudi Arabia and Tokyo are the most sensitive stock markets toward terror attacks. 


\section{References}

i. $\quad$ Abadie \& Gardeazabal, 2005. Terrorism and the World Economy. [Online] Available at: https://addiehu.ehu.es/bitstream/10810/6734/1/wp2005-19.pdf [Accessed 25 December 2016].

ii. Aljazeera, 2016. Aljazeera News. [Online] Available at: http://www.aljazeera.com/news/2016/o7/saudi-arabia-qatif-explosion160704165007140.html [Accessed 25 December 2016].

iii. $\quad$ Arin \& Spagnolo, 2008. The Price of Terror: The Effects of Terrorism on Stock Market Returns and Volatility. [Online] Available at:

https://www.researchgate.net/profile/K Arin/publication/223663916 The price of terror The effects of terrorism on stock market returns and volatility/links/56c969oeo8ae96cddo6bc85 6.pdf [Accessed 25 December 2016].

iv. BBC, 2016. BBC News. [Online] Available at: http://www.bbc.com/news/world-middle-east29319423[Accessed 25 December 2016].

$v$. Behavioral Fianance, 2003. Sciencedirectcom. [Online] Available at: http://www.sciencedirect.com/science/article/pii/Sog27538X03000489 [Accessed 25 December 2016].

vi. Behavioral Finance, 2016. Investopedia. [Online] Available at: Behavioral Finance: Introduction | Investopedia [Accessed 25 December 2016].

vii. CFA Pubs, 1974. Risk, Market Sensitivity and Diversification. [Online] Available at: http://www.cfapubs.org/doi/pdf/10.2469/faj.v51.n1.1863[Accessed 25 December 2016].

viii. Eliott, C., 2016. CNN. [Online] Available at: http://edition.cnn.com/2016/03/29/europe/hijackedegypt-air-jet/[Accessed 25 December 2016].

ix. $\quad$ Finance, B., 2007. Albert phung: Investopedia. [Online] Available at: http://www.investopedia.com/university/behavioral finance/ [Accessed 25 December 2016].

x. Hassan \& Hashmi, 2015. Terrorism a nd the Response of Investors at Capital Market: A Case of Pakistan.. Pakistan Journal of Commerce and Social Sciences.

xi. Investopedia, 2010. Durbin Watson Statistics: Root. [Online] Available at: $\underline{\text { http://www.investopedia.com/terms/d/durbin-watson-statistic.asp }}$ [Accessed 25 December 2016].

xii. $\quad$ Kumar, S., 2013. Impact of Terrorism on International Stock Markets. Journal of Applied Business and Economics .

xiii. NBER, 2016. Financial Market Integration is a Central Concept in International. [Online] Available at: http://www.nber.org/digest/jang9/w6724.html [Accessed 25 December 2016].

xiv. New York Times, 2016. Chelsea Explosion New York City. [Online] Available at: ttp://www.nytimes.com/2016/o9/18/nyregion/chelsea-explosion-new-yorkcity.html? $\mathrm{r}=0$ [Accessed 25 December 2016]. 
xv. PDPE, 2007. Market Analysis Tool: Market Integration. [Online]

Available at:

http://documents.wfp.org/stellent/groups/public/documents/manual_guide_proced/wfp18 7901.pdf [Accessed 25 December 2016]. Sewel, M., 2010. Behavioral Finance. [Online]

Available at: http://www.behaviouralfinance.net/behavioural-finance.pdf [Accessed 25 December 2016].

xvi. Tasfoura, A., 2012. Impact of Terrorism on Stock returns: Evidence from Pakistan. [Online] Available at:

http://pakistansocietyofvictimology.org/Userfiles/Impact\%20of\%20Terrorism\%20on\%20 stock\%20returms,\%20Evidence\%20from\%20Pakistan.pdf [Accessed 25 December 2016]. 